\title{
Growth-based Theories for Declining Regions? A Note on Conceptualisations of Demographic Change for Regional Economic Development
}

\author{
Anke Matuschewski, Birgit Leick, Marcel Demuth
}

\begin{abstract}
This article aims to critically assess the economic growth paradigm, which typically underlies most approaches to regional policymaking for demographic change. While population losses, ageing and outmigration -i.e. phenomena that are addressed as demographic change - have become a matter of urgency for many European regions, most regional economic development theories remain silent about the population decline affecting the economic growth and development prospects of regions. Consequently, regional policies usually rely on the concept of economic growth, yet neglect the complexity and importance of demographic change and how it relates to the economic sphere. Due to this lack in nuance, we argue that regional policymaking fails to design adequate policy support for regions facing persistent demographic change and economic stagnation or decline as a result. Based on these observations, the paper examines a selection of regional economic development theories in search for alternative concepts of growth and development in the context of demographic change. To this aim, globalisation peripheries are introduced as a fruitful conceptual point of reference and, in combination with endogenous regional development theories, discussed as an alternative approach for regional policymaking.
\end{abstract}

Keywords: Demographic change $\cdot$ Economic growth theories $\cdot$ Regional economic development $\cdot$ Globalisation peripheries $\cdot$ Regional policies

\section{Introduction}

Many countries across Europe and elsewhere (e.g. Japan or the PR of China) are experiencing profound and long-term demographic challenges, such as population ageing and decline and increasingly heterogeneous populations (Goldstein/K/uge 2016; Niephaus et al. 2016; Bloom/Canning 2008). In fact, these challenges and processes are the result of decreasing fertility rates and increasing longevity and mi- 
gration, originating from shifts in lifestyle, attitudes and an ever-rising standard of living. These processes will change the face of many European economies and societies quite dramatically (van der Gaag/de Beer 2014). For example, as Fuchs et al. (2010) or Gunkel and Henn (2016) show, demographic change in Eastern Germany significantly alters the long-term economic growth prospects for a region which has already lost part of its workforce due to outmigration and ageing. In this article, "demographic change" refers to population ageing and decline.

Without a question, demographic change is a major factor of regional economic development across many European regions. However, despite the large public and political debates about the challenges ahead (e.g. an ageing workforce, bottlenecks on labour markets, the public pension system or service provisions), academic discussions on demographic change in economics, regional economics and economic geography only partially touch on these challenges (Hanink 2010: 18-23). This observation, as we think, has its roots in the fact that many mainstream theories and conceptual approaches neglect or simplify demographic change and its effects on economic development. Consequently, it is hard to find any references to demographic change and stagnation or decline within the established theories of regional growth (sic!) and development in economics and other social science disciplines (Martin 2015; Schulz 2012). Hence, most of the academic literature gives inadequate answers to the question of how demographic and economic processes are interrelated, particularly in the context of stagnation and decline, and what can be learnt from this interrelationship for contemporary demographic challenges.

This criticism becomes even more relevant when it comes to economic policymaking. As many approaches focus on the economic success and competitiveness of regional economies without addressing population size and change, they tend to overlook demographic processes as a factor influencing the long-term growth prospects of regions and the potential levers for policy interventions. Indeed, many regional policy approaches rely on growth-oriented paradigms (Haase et al. 2016a; Wiechmann/Pallagst 2012) that have their origins in economic modelling; meaning that counteracting the challenges associated with regional decline and stagnation, be they in the demographic, economic or both spheres, implies returning to a growth as quickly as possible. Often, these approaches and the resulting policymaking do not explicitly consider conditions of stagnation and decline beyond short-term deviations from a pre-determined path of economic growth. Accordingly, recommendations that are derived from this ideal-type of - in economic terms - growing and successful regions are made, irrespective of the demographic status quo or outlook of regions. However, it makes little sense to apply "best practice" policy strategies that are drawn from growing regions to demographically changing and therefore declining regions, because such policies are highly likely to fail and neglect the specific needs of regions facing decline or stagnation beyond temporary downturn.

Against the backdrop of these observations, this paper aims to adopt a critical stance towards both the growth-based paradigm in regional economic development theories and the prevailing approaches to policymaking for regions affected by demographic change. The paper therefore addresses how the systemic nexus of demographic-economic change is represented in the main concepts of regional 
economic development and establishes points of departure for conceptualising a more adequate understanding of regional economic development for demographic change. This alternative understanding uses the concept of so-called "globalisation peripheries" to link complex phenomena in the demographic-economic spheres, which imply regional stagnation and decline. Besides contributing to a more adequate conceptual understanding of the demographic-economic dilemma from a regional perspective, the globalisation peripheries approach is also open to policymaking in that it considers specific local development trajectories. The basic premise of this article is therefore that in the light of demographic change as a systemic and long-term process involving stagnation and decline, it is necessary to move beyond strictly growth-based policy approaches and develop open, non-normative ones. A core challenge, then, is that the decline and stagnation associated with demographic change should be accepted as long-term conditions of economies and societies, which can and should be proactively shaped through policymakers. On these grounds, and in line with the arguments proposed by Müller (2003) and Friedrich and Woon Nam (2009), we call for paying greater attention to demographic and/or economic stagnation and decline in the practice of policymaking as these conditions become reality in many European regions. This approach, however, is quite different from the usual practice of copy-pasting growth strategies (such as industrial clusters or innovation policies) to regions facing demographic-economic decline.

The remainder of this article is structured as follows: After introducing the relationship of demographic and economic growth based on a literature review, the paper critically focuses on the main conceptual approaches that examine this relationship on the level of regional economies, searching for ideas on how to conceptualise stagnation or decline as the opposite of growth. The next section discusses globalisation peripheries as an alternative theoretical approach, which more realistically describes long-term conditions of demographic-economic stagnation and decline. Finally, the paper proposes ideas for new policy approaches in the context of demographic change which are associated with the acceptance of decline and stagnation as long-term phenomena, the activation of endogenous local potentials and, to achieve this, proactive coping strategies.

\section{Demographic change, regional economic development theories and policymaking: state-of-the-art}

\subsection{On the relationship between demographic and economic change}

Western European economies have long faced what can be described as a postMalthusian growth regime. Since the 1960s, fertility rates and population growth have slowed down, while economic standards of living and income levels have risen (Feng/Yang 2007: 49; Poot 2008). In times of demographic change, this relationship has been increasingly challenged, with population ageing and population decline 
becoming manifest. Hence, recent contributions by scholars such as Batey (2016), van der Gaag and de Beer (2014), Liao (2011), Weber (2010), Headey and Hodge (2009), and the collection of papers in Prskawetz and Lindh (2007) explore the relationship between demography and economic growth in phases of demographic change in the tradition of macro-economic models for the political economy.

Generally, Poot (2008: 131) observes a striking asymmetry in the research on the potential interdependencies between economic and demographic change: While the influence of the economy on the demography of a nation can be explained and modelled well, the opposite does not necessarily hold true (Küpper 2015). A general problem occurring in this study is what Headey/Hodge (2009: 221) describe as follows: "a stylized fact in the macroeconomic literature on population growth is the absence of a robust effect of total population growth on economic growth". Moreover, mainstream economic theories have some difficulties considering systemic endogenous change. This is partly due to the complexity and the systemic character of internal change processes, which does not fit the fundamental theoretical assumptions and deterministic thinking of neoclassical or Keynesian growth models (Aghion/Howitt 2009). In addition, different isolated demographic variables might counteract each other in a way that offsets negative and positive effects, a finding that has been called the "population neutralist view" in economic modelling (Bloom/Canning 2008: 26).

Closely related to the previous and general argument is the fact that neoclassical growth models traditionally consider economic growth as determined by technological growth and change, rather than by population change (Ehrlich/Lui 1997). However, Dalgaard/Kreiner (2003) argue that endogenous and particularly "semiendogenous" growth models may well capture population decline and model economic growth prospects, based on an innovation-driven growth path. Still, many of the recent macro-economic models focus on the relationship between population and economic growth, but not on decline. For example, Headey/Hodge (2009) find that a growing working-age labour force is associated with economic growth, whilst the opposite may not necessarily be true. Liao (2011) shows that demographic change caused by rapid fertility decline in Taiwan has adversely affected the country's economic growth, but that the negative effect can to a large part be offset by productivity gains.

Some recent contributions use more sophisticated modelling such as Computable General Equilibrium (CGE) analysis to explore demographic change and its effect on economic growth, yet focus on isolated effects (Batey 2016; Lisenkova et al. 2010; Gaigné/Thisse 2009). For example, Lisenkova et al. (2010), computing a CGE model for Scotland, find a negative effect of demographic change on regional economic growth. In contrast, Prettner (2013: 831) who computes changes in the size of the population and age structure and their effects on the long-term economic growth in an endogenous growth model through technological progress, observes that increasing life expectancy is associated with higher growth rates in this constellation, while the opposite is true for falling fertility rates.

To summarise the results of these CGE-based models, the overall impression is that a declining or ageing population has a depressing impact on economic activity, 
a finding which is neither astonishing nor uncontested, as Börsch-Supan (2013) emphasises. Most empirical analyses illustrate that both the intensity and direction of demographic change on the economy are far from being clear or even unidirectional (Küpper 2015). Due to the high degree of complexity of translating demographic processes into macro models and because of the specific model conditions, it is often difficult, and perhaps impossible, to completely grasp the dimensions of the impact that demographic change has on the economy and vice versa without going back to theories and approaches that explain the causal relationships.

\subsection{Demographic change and its effects on regional economies}

What seems to be clear is that demographic change affects regional economies in different spheres and through various channels (Davoudi et al. 2010). An important transmission mechanism of demographic change on the economy is the public and fiscal sphere. McMorrow and Roeger (2004) show that rising pressures on public expenditures and life-cycle effects on private savings (partly due to a deterioration of public savings) are direct effects on the level of economic activity. Age-sensitive areas in which fiscal consequences of demographic change will become evident include the pension, health and educational systems. All other things being equal, reduced tax volumes and public payrolls will be likely to induce growing public expenses (Bloom et al. 2003; Misoulis 2008). While national public savings will probably be negatively affected by demographic change, depending on the welfare and pension system (McMorrow/Roeger 2004; Disney 2000), the impact on private savings can be forecast less precisely.

By contrast, the effect of demographic change, particularly the decline in total population, on the provision of public goods and services such as the maintenance of technical and social infrastructures is clearly negative (Poterba 1998; Prskawetz) Lindh 2007). Providers of water supply and sewer systems, schools and educational bodies, libraries, public transport or other services are confronted with decreasing or structurally changing demand (Naumann/Bernt 2009). As for public infrastructure, such as transport, or water and energy supply, the problems associated with demographic change have been well-analysed and described (Steinführer et al. 2014; Haase et al. 2016b; Haug 2004). A falling demand raises the costs for the provision of services, because fixed costs must be shared among fewer inhabitants (cost hysteresis). Maintenance costs will tend to rise and put a strain on the public budget, unless they are redistributed among the remaining users.

Demographic change also has direct and strong effects on labour markets (Ermisch 1995; Bloom/Canning 2008; Leibfritz/Roeger 2008) as the workforce ages or declines due to retirement (Poot 2008; Brunow/Hirte 2006). The most obvious impact will be a decreasing labour supply due to an ageing workforce or outmigration (Brown/Danson 2003; Fuchs et al. 2008). Vice versa, large and growing workingage cohorts can improve the economic growth prospects of regions (Brunow/Hirte 2006; Bloom/Canning 2008). In theory, a declining working-age population, seen as a shrinking labour force, would induce higher labour costs for firms, forcing employers to maintain or raise their productivity level (Feyrer 2008). In this case, demo- 
graphic change will challenge enterprises to invest more in research and development (R\&D) and human capital formation in order to sustain their competitiveness. As Börsch-Supan $(2008,2013)$ and Faggian and McCann (2009) argue, R\&D and human capital investments are equally important public policies for supporting regional economies in coping with changing labour markets caused by demographic change. Particularly for regions facing long-term population decline and outmigration, relying on a positive net inward migration is a rather unrealistic option (see, for instance, Lisenkova et al. 2010; or BMVDI 2016).

Liao (2011) argues that demographic change in fast-growing developing nations can stimulate economic growth through a shrinking dependency ratio, less expenditures for youth and growing human capital accumulation. This scenario is based on benefits from the so-called "demographic dividend" (Bloom et al. 2003). A likely scenario for economies facing demographic change is the deceleration of innovativeness and technological progress and even a resistance to technological change among ageing and declining populations facing increasing dependency ratios. This effect may be caused by a lack of young, innovative labour force, shrinking market potentials and divestment by firms (Cutler et al. 1990; Dixon 2003; Poot 2008). In fact, Bönte et al. (2009) and Harhoff (2008) point to an age-related decrease in entrepreneurial activities and new firm foundations due to demographic change, which negatively affects the innovative potential of demographically ageing economies because the acceptance and adoption of innovation tend to be lower in ageing societies (Canton et al. 2002).

At the level of the industry structure, new consumer preferences will emerge because of shifts in the demand for goods and services between ageing and young consumers (Koh/bacher/Herstatt 2011), which will affect the prospects for certain industrial and service sectors (Poot 2008). Rosenfeld $(2003,2006)$ has shown for Germany that particularly consumer-oriented businesses would be affected by demographic change, depending on price and income elasticities. Examples of industries where a strong impact is highly likely are clothing and textiles, pharmaceutical goods, food, and education. Firms operating in such sectors and serving local-regional markets might need to adjust their business models towards ageing consumers and changing demand.

Börsch-Supan (2013: 4-5) elaborates that demographic change does not automatically lead to a sinking standard of living for households. However, as Kohlbacher/Herstatt (2011) highlight, all consumer-oriented industries will have to cope with the preference for higher-quality goods and services shown by wealthy elderly consumers on the one hand, whilst, on the other hand, poverty is on the rise among elderly people in demographically declining nations such as Germany (see, for example, Goebel/Grabka 2011). More generally, there will be demand-side changes due to age-specific requirements, particularly in health, leisure, travel and specific household services. At the level of individual industries or regions, this might result in an increase in potentials in so-called "silver" niche markets (Kohlbacher/Herstatt 2011). Using the region as the unit of analysis, we can assume that the share of these consumer-oriented sectors in a region's industrial structure will determine the de- 
gree to which demographic change affects the regional economy through shifting consumer preferences (Küpper 2015).

These examples show how demographic change can have an impact on the economy. Particularly in regions that face population decline and aging, these effects will strike far harder than in regions with a growing or stable population. While most economic models do not address the level of the region (with the exception of Brunow/Hirte 2006; Lisenkova et al. 2010; Kim/Hewings 2013), regional and urban researchers have been exploring the multi-level challenges associated with regional economies and demographic change for a long time (Winkel/Spiekermann 2014; Wirth et al. 2016; Haase et al. 2016b). Therefore, policies to mitigate the associated challenges are an important element of regional economic adaptation to demographic change.

\subsection{Policy responses resulting from an exploration of the demographic- economic relationship}

Clearly, policy is a crucial element in responding to and directing demographic change (Ferry/Vironen 2011). However, the adequacy of such policy responses rather than demographic change itself - may be the primary challenge, as Bloom et al. (2010: 607) state: "The problem of population ageing is more a function of rigid and outmoded policies and institutions than a problem of demographic change per $s e^{\prime \prime}$. Recent contributions such as the special issue of the Oxford Review of Economic Policy $(26,42010)$ thus stress the need for not only describing the outcomes of demographic change in the economic models, but also for devising adequate policies to mitigate these effects on the macro-economy.

Martin/Sunley (1998) provide a summary of the main channels that macro-economic growth models propose as starting points for policymaking: (1) human capital, and (2) technological progress and innovation. This focus of most regional policy approaches is backed by recent contributions suggesting investments in human capital (Mason et al. 2016) and public investment in education to offset negative effects of ageing on human capital formation (Kim/Hewings 2013). Replacement migration is another solution for an ageing workforce proposed by some economists and policy-makers, though it faces limitations (Bouvier 2001; Azarnert 2010). Bloom et al. (2010) and Hammer et al. (2015) also recommend increasing ageing societies' labour participation, for example through enhancing engagement of elderly persons and women of working age. Many national governments have recently been seeking adequate responses to mitigate adverse effects of demographic change, whilst developing strategies for capitalizing on the potential benefits (Ferry/Vironen 2011).

However, despite these recent trends, most development strategies for regions facing demographic change rely on growth-based approaches such as Michael Porter's cluster concept (Porter 1990), which has been adopted as "the magic bullet" (Martin 2015: 266) on different spatial scales, ranging from the European to the national and regional levels. Prominent examples are the European cluster strategy, the German national programmes "InnoRegio" and "BioRegio," as well as local policies in the German federal states of Bavaria and North Rhine Westphalia. Conse- 
quently, the prevailing policy of such programmes is to copy-paste an "ideal type" of economic development, e.g. the way Silicon Valley developed, to other regions, which Bristow (2005: 296) comments as follows: “(w)hat is missing is any effort to conceptualise regions as territorially defined social aggregations, with very different economic and political structures". While it is, of course, problematic to imitate economic development processes by applying recipes that are based on very specific local contexts and their political-institutional settings, this is even more the case when one keeps in mind that the "miracle" of Silicon Valley was virtually free from policy interventions. Other popular approaches include the concepts of industrial districts, "milieus innovateurs" (Camagni 1991), or regional innovation systems (Asheim/Gertler 2006; Ne/son 1992), which stress the importance of industry agglomeration and an innovation-based industry, or the creative class (Martin 2015; Bristow 2005) that focuses on highly skilled migration as a growth inducing factor.

Indeed, most public policy approaches for dealing with demographic change are based on the idea that the experience of "best practice" cases of prospering regions can be transferred to regions facing demographic change, often coupled with economic decline or stagnation. It is, however, more than questionable to use such policy strategies for regions with starkly different economic, political and institutional conditions or specific demographic challenges such as population decline or rapid ageing. Additionally, this approach neglects the complexity of demographic processes which unfold on a set of different layers and fields in the regional economy (Tyers/Shi 2012). Particularly in the case of regions that face long-term decline or stagnation, innovation-based regional development is hard to achieve, because these regions do not provide the economic structure that such theories emphasise (for instance: agglomeration economies, labour market size and structure, firm size and structure, business networks, and institutional thickness, notably R\&D-related institutions; Küpper/Margarian 2010; Meng 2013).

For example, rural-peripheral areas face long-lasting periods of stagnation or decline in terms of their population and economic growth prospects; often hosting mature or "low-technology" industries and lacking a critical mass of enterprises to provide innovative activities (Noronha Vaz 2006; Copus/Skuras 2006; Huggins/ Johnston 2009; Meng 2013). Demographic change then exacerbates the economic weaknesses when shortages of labour supply for higher-value-added industries occur due to outmigration and population ageing. Meng (2013: 181) points to the fact that innovation taking place in non-agglomeration areas is mainly incremental and not represented in established indicators for innovation (such as patents). In a similar vein, Küpper/Margarian (2010) stress that process innovations are a more common type of innovation for rural areas. According to Fuduric (2012), much of this also holds true for entrepreneurship in regions facing decline or stagnation due to a lack of individual resources and adequate institutional settings for entrepreneurial activities, such as financial intermediaries or consultancies for newly founded firms. Although local entrepreneurship may foster economic growth in some rural regions (see, for example, Meili/Mayer 2015 for Swiss rural areas), most entrepreneurship analyses such as the Global and Regional Entrepreneurship Monitor (Sternberg 2005; Wagner/Sternberg 2005; Meng 2013) indicate that regions located outside ag- 
glomerations often lag in terms of entrepreneurial activities. Thus, changes in entrepreneurial and innovative behaviour associated with demographic change (Bönte et al. 2009; Harhoff 2008) pose an additional challenge to these kinds of regions.

Even more radical is the criticism that Russell/Vinsel (2015) express about the importance of innovation. For them, innovation has become a sort of fetish in Western industrialised economies, and concepts such as regional innovation systems or "milieus innovateurs" have fed policy and planning strategies with arguments and measures to mainly support innovation that is associated with technology (OECD 2009a). According to them, it is crucial to understand that technology cannot be equated with innovation and "innovation is only a small piece of what happens with technology" (Russel//Vinse/ 2015: 10). Instead, societies should also focus on maintenance of the basic material infrastructures (bridges, roads, railroad tracks, etc.), which are in danger of being neglected in industrialised countries such as the United States, the UK or Germany. The maintenance of transport, repair or even laundry services also needs established and traditional technologies and networks, firms and workforce providing know-how.

Taking up this rationale for the issue of demographic change and policy responses, regional policy strategies often neglect the questions of whether and what kind of innovation can be a useful remedy for a given region and context, as the preconditions for innovation-based technological progress strikingly differ between regions (Crescenzi/Rodriguez-Pose 2012; Crescenzi et al. 2007; Fagerberg et al. 1997). Notwithstanding this observation, R\&D investments and innovation performance are deemed important indicators and drivers of regional economic growth and development (Crescenzi/Rodriguéz-Pose 2012) and, consequently, the backbone of most policies that aim at enhancing regional competitiveness (Bristow 2005).

\subsection{Demographic change, theories and economic development: a synthesis}

As we contend, the common arguments used for both growth-oriented regional policymaking and its practice need alternative ideas for addressing economic development in times of demographic change. As an endogenous and systemic process, demographic change has far-reaching, long-term effects on the population size and structure and, consequently, influences the development prospects of regional economies and societies on multiple layers over time. Moreover, it affects different groups of actors that are embedded in regional economies: private enterprises, the public sector including public corporations and agencies, and civic actors. Policy strategies may therefore influence demographic change at the national and subnational level in various respects and through different channels.

Regarding economic development theories and concepts, population change (growing, shrinking or constant population) is seldom directly conceptualised. Macro-economic growth models often delimit the relevance of demography to migration processes which function as a mechanism to outweigh disequilibria of income or labour force (Aghion/Howitt 2009; Lisenkova et al. 2010). Partly because of the underlying neoclassical paradigm, and partly due to the fact that most re- 
gional development approaches in economics and economic geography rely on the paradigm of economic growth, many theories do not offer points of departure for describing endogenous change processes originating from demographic shifts or social dynamics (Martin 2015). Moreover, the dynamics of demographic change processes tend to take place in a slowly evolving manner with long-lasting effects that cannot always be identified immediately, which makes timely recognition and immediate political reaction difficult (Matuschewski/Leick 2012).

\section{From change to decline and stagnation: A different perspective for conceptualising regional economic development for demographic change}

Based on this criticism, it is argued in this paper that economic development for configurations of regional decline and stagnation - as is the case in times of demographic change - should be extended to encompass qualitative improvements paralleling purely economic processes. Such an alternative understanding is reflected in the concept of "globalisation peripheries".

\subsection{Notions of decline, stagnation and development}

Searching for a conceptual foundation of these phenomena, however, terms such as "stagnation", "shrinkage" or "decline" hardly appear in the established regional studies readers for postgraduate students. For example, neither the tables of contents nor the indices of the following textbooks and research volumes mention these terms: Bröcker/Fritsch (2012), Coe et al. (2013), McCann (2013), Pike et al. (2011), Stimson et al. (2006), Armstrong/Taylor (2000), Clark et al. (2000), Liou (1998), Storper (1997) and Blair (1995). If addressed at all, the most common term is "decline", which is mentioned in one chapter by Capello/Nijkamp (2008) and Leyshon et al. (2011). Lombardini (1996) lists "stagnation" in the index of his book. We can only assume that the omission of these terms in most regional studies textbooks and readers might be due to the fact that the focus of authors and editors is clearly fixed on growth. In this respect, Breinlich et al. (2014: 755) concede that the notion of decline has no fixed meaning: "Regions could be declining in terms of absolute or (more often) relative living standards and welfare indicators, but also in terms of absolute and relative population, since one response to economic decline will be out-migration and diverted in-migration. This second kind of decline is often a symptom of the first, but has interest in itself, as a distinct process".

More recently, notions of "development" have been discussed as useful alternatives to overcome the normative dichotomy of "growth" versus "decline". Pike et al. (2016) illustrate that both the perception and definition of the term "development" have undergone significant changes over the past years. A change in perception took place as scholars pushed for a wider definition including qualitative, social and environmental aspects to overcome the one-sided fixation on economic growth as an overarching paradigm (Haase et al. 2016a; Wiechmann/Pallagst 2012). On the 
global scale, this trend is, for instance, reflected in a methodological extension towards more complex and broader indicators measuring development such as the Human Development Index (HDI), the Human Poverty Index (HPI), the Gender Inequality Index (GII) or the Sustainable Development Goals (SDGs) of the United Nations. The most important difference is that the notion of "development" embraces sustainable qualitative improvements in economic wellbeing and living standards, which do not solely depend on economic growth, but consider the capabilities and resources of nations or parts of the world (Clark 2005). According to these recent changes and our own understanding, "development" primarily refers to qualitative, and perhaps incremental, changes of a system, instead of quantitative change only. Accordingly, processes of democratisation or participation, technological modernisation, improved labour conditions, better governance and institutions, or a more even distribution of income and wealth are some of the mechanisms to achieve economic development, without necessarily and immediately materialising in quantitative economic growth (Stiglitz 2001; Durth et al. 2002; Sen 2001). Pike et al. (2016) highlight that alternative measures for local development based on qualitative indicators have, however, not yet been established.

Regarding demographic change, development is associated with change in elements of the system, such as lifestyle, the structure or age composition of a population, social cohesion and inclusion. Each element implies a different functioning and direction of the system as a whole. Accordingly, a region facing demographic change can experience socio-economic development when (re)distributions of work time and employment or reallocations of wealth take place, or because a change in the local social networks supports qualitative improvements and development despite quantitative decline. Given the complexity of such change, it is, however, difficult to quantify or measure such processes with the most common macro-economic indicators (for example, a region's GDP). For example, non-market based voluntary work is not included in the GDP, but often complements or even compensates for state- or market-based services in stagnating or declining regions because of institutional and organizational thinness. Examples from Eastern Germany stress that civic initiatives supplement the public transport and educational system, for instance through small schools or private bus transport organisations operated by local citizens in demographically declining regions. In this case, economic development, which includes broad civic engagement and social networks, will be difficult to quantify using the common statistical indicators.

Thus, factors that support social cohesion and build local social capital form part of the regional human capital stock, each of them representing basic endogenous potentials (Hahne 1985). Regional development in that sense can contribute to a better resource endowment of regions and support their long-term resilience (Bristow/Healy 2014; Lang 2012). However, these elements are typically not represented in growth-oriented policy approaches. 


\subsection{Theoretical reference points for conceptualising "decline" and "stagnation"}

Besides the question of what development can mean for regional economies facing demographic change and decline, a general problem with many regional economic development theories is that the importance of demography is limited to labour or human capital endowment and mobility. Other effects of demography on regional economies - such as the impact of a falling birth rate and population ageing on regional demand, the distribution and performance of established firms as a consequence of (failures of) company succession and lower levels of entrepreneurship - have been hardly addressed to date. Even if the fundamental relationship between demographic or social processes on economic development is explicated, stagnation or decline as a phenomenon resulting from demographic change is considered only as short-term transitional deviation from growth periods or as an external, shock-like crisis which disturbs a normatively pre-determined path of economic growth, implying that positive growth will "naturally" return in the future (Harrigan et al. 1992; Richardson 1973). Only a few theories and concepts offer points of departure for explaining configurations of lasting decline or stagnation, as opposed to growth and causes of cross-regional disparities in the context of demographic change. Among these approaches are Post-Keynesian theory and Myrdal's theory of regional polarisation, endogenous regional development theories, and the concept of "lock-in" as a path-dependent process.

Post-Keynesian and polarisation theories explicitly describe stagnation and decline as distinct regional development paths, thereby proposing an alternative to economic growth. Post-Keynesian theory claims that external investment affects regional income and production capacity through direct and complementary effects, which, in turn, lead to a rising differentiation between growing, stagnating or declining regions. The initial trigger is an exogenous force such as investment, whereas endogenous factors, which may also influence regional production and income, are not considered. Social change, such as lifestyle changes that lead to a dropping fertility rate and result in demographic change (as we can observe in many industrialised nations today), is not addressed in Post-Keynesian thinking. Moreover, it is argued that with higher levels of regional growth and development, intraregional disparities are likely to decrease due to spatial spill-over effects and rising costs of agglomeration. Yet, even Post-Keynesian economists are predominantly focussed on growth paths of the economy (Setterfield 2010).

Regional polarisation theory (Myrdal 1974) is the only approach that explicitly deals with processes of (long-term) decline. Using the notion of "cumulative causation", the connections between economic and non-economic mutually reinforcing processes of decline are described. Indeed, the discussion of the relationship between economic, demographic and fiscal processes is at the very centre of Myrdal's approach. Many of Myrdal's findings from 50 years ago can be confirmed with contemporary examples of regional decline (Steinführer 2015). The picture of cumulative causation is highly impressive, because it vividly alludes to the impact and interdependencies of economic and demographic decline (Feng/Yang 2007). However, it 
is, again, an external and random impulse to set a process of cumulative (negative) causation in motion leading to regional decline (Myrdal 1974). Demography is also limited to migration as both consequence and cause of economic decline. In the thinking of Myrdal's regional polarisation theory, demographic change could imply a downward spiral of regional development, forcing firms and households to abandon their home region and move to growing or stable economies (Feng/Yang 2007).

Despite these insights into the causes and complexities of decline, the descriptive character of regional polarisation theories suggests that the ultimate consequence of the downturn loop will be deserted regions, because the theory's adaptive reactions are dichotomous: either "exit" the region or "stay and shrink". The drastic scenario of the complete depletion of once prospering, and now "sclerotic" regions is a very unlikely one, although it did emerge in the political debates among regional planners discussing Eastern Germany's future in the late 1990s, for example (Steinführer 2015). Regarding policy implications, public intervention serves as the primary means to halt the downturn loop according to Myrdal, while endogenous factors to enter a new path towards growth are not addressed. Consequently, inspirations for policymaking for non-growing regions drawn from these approaches remain limited. Even the extensions and elaborations of Myrdal's theory, such as the "polarisation reversal" or "centre-periphery" approach, which distinguish between "trickling down" versus "polarisation effects", do not overcome the deficiencies of the theory (Hirschmann 1958; Friedman 1966; Richardson 1980).

Endogenous regional development theories are a counter-approach to these concepts. They emerged in the 1980s in response to growing criticism of the oncedominant argument that exogenous forces would be the drivers of regional growth, thus favouring development via "bottom up" channels as explanation (Maier/Tödtling 2002: 193; Hahne 1985; Stöhr 1981). The Austrian regional researcher Walter Stöhr (1981) was among the proponents of this (at the time) novel approach to regional development. Yet his arguments mainly refer to (under-) developed countries in the global context. Nevertheless, the general rationale of the approach can be adapted to the local or regional level (Hahne 1985), stating that it is not exogenous investments, but endogenous forces pushing regional economies to grow and develop, as regions do often not experience sufficiently strong external investment flows or other impulses. Thus, regions must expand their endogenous potentials when striving for economic development.

The term "potential", however, remains quite vaguely defined and needs further interpretation. In a broader sense, the local "potentials" comprise all material and immaterial resources that a region possesses, including infrastructure, population, financial resources, market potential, and social, environmental and cultural assets (Harfst/Wirth 2014). From a policy perspective, endogenous development approaches aim to activate unused or underused potentials and overcome their limitations (such as poor transport infrastructure, human capital scarcities or an unfavourable local image) to drive economic development by enhancing local capacities. Contrary to most economic approaches, this theory is based on a quite different understanding of regional economic policy, one that emphasises development rather than growth, although the latter might be a long-term goal for the 
region. Moreover, this approach offers what Bristow (2005) advocates, i.e., viewing the individual characteristics, both strengths and weaknesses, of regions.

Evolutionary concepts offer a complementary perspective on decline, which emphasizes context-specific regional settings and understands regional economic development as path-dependent trajectories that are open to future developments and are self-transformed from within (for example, through political and business decisions). Local actors, their networks and decisions determine the historical creation of a specific regional path and its development over time, leading to either growth, stagnation or decline (MacKinnon et al. 2009; Boschma/Martin 2007; Martin/Sunley 2006; Boschma/Frenken 2006). Time- and path dependencies are associated with mechanisms through which past decisions influence future development processes and decisions by both limiting and guiding them, although contingency and chance may influence path-dependent regional development through sudden incidents (Boschma/Frenken 2006). Firms are considered to be key actors, shaping the region with their competitive behaviour and time- and path-dependent economic decisions (Boschma/Frenken 2006; Martin/Sunley 2006). In addition, institutional settings, including informal institutions such as social networks, and institutional changes (Cortinovis et al. 2016; MacKinnon et al. 2009; Boschma/Frenken 2011) shape these path-dependent trajectories. For the discussion on demographic change, the phenomenon of "lock-in" seems to be especially important (Henning et al. 2013; Hassink 2010) because it describes and explains the effect of an increasing "crustification" of regional economies due to an over-specialisation in non-competitive industries, overly close local actor networks with tight inter-dependencies, failing economic policies, or other functional, political, technological or cognitive "lock-in" constellations (Grabher 1993). From an evolutionary perspective, breaking an established path and "delocking" are important targets to counteract the stagnation or decline of locked-in regions (Martin/Sunley 2006).

\subsection{Globalisation peripheries as an alternative approach to understanding decline and stagnation in the context of demographic change}

The concept of globalisation peripheries complements the conceptual ideas about decline and stagnation emerging from the established regional economic development theories. German development geographer Fred Scholz $(2004,2007)$, who stands in the tradition of the global development school, introduced the concept to describe peripheralised and both economically and socially marginalised spaces, ranging from entire nations to regions or even city districts. His multi-scalar idea of "globalisation peripheries" conveys the picture of losing areas, which are being decoupled from global economic dynamics and have no - or at best low - prospects for economic recovery and sustainable economic development. Being neither the sites of the majors drivers of economic activities, the locations of key actors (such as transnational companies or global organisations), nor integrated into global production networks and value chains, key actors on the global scale such as large corporations and organisations typically overlook globalisation peripheries. From 
their perspective, such regions are either too small as consumer or labour markets or too scarcely endowed with resources, be they natural, infrastructural, or human capital. With this picture, Scholz $(2004,2007)$ paints a drastic image of depleted and marginalised regions or nations that fits many developing nations in the Global South (Scholz 2003).

Because of its broad perspective on persistent "non-growth" in multiple interconnected spheres, the concept depicts the prospects of demographically declining regions across Europe quite appropriately, illustrating demographic change and its inter-relationship with economic change. Such complex phenomena can have different origins, such as the former system transformation in Eastern Europe, the deindustrialisation of former hubs of pre- and post-war heavy industries and industrial production in Germany or the United Kingdom, youth outmigration and population ageing in notably rural regions outside the core city regions and agglomerations across Europe, or economic downturn in the aftermath of the recent global financial and economic crisis in Southern Europe, which has led to outmigration of highskilled young workers (see Martin 2015; Martin et al. 2016). These regions all face continuous economic crises, which go far beyond short-term recessions, with only weak signs of recovery (see Doran/Fingleton 2016 for EU employment data).

Thus, in the parlance of Scholz' $(2004,2007)$ concept, a number of European regions including the ones facing significant demographic decline can be labelled as globalisation peripheries, because they face multiple challenges in the economic, social, political and demographic spheres that cannot be solved through quick fixes or external stimuli. The concept can be used to explicitly describe the inter-relationship between demography and the economy as a systemic complex of multilayered challenges. Peripheralisation is one major characteristic of Scholz' original model that fits remote European regions which are located at some spatial distance from the core capitals and major cities and are, in addition, decoupled from substantial economic activities (Lang 2015; Lang et al. 2015; Kühn 2013; Kühn/Bernt 2013). Additionally, many of these regions also suffer from demographic change coupled with long-term economic stagnation or decline, i.e. perspectives of nongrowth in the core sense. As a result, cases of European globalisation peripheries are not affected by isolated problems alone, but are marginalised through their low economic power and dynamics, the structure of their population and its social stratification, and a low degree of global integration (Bernt/Liebmann 2013; Danson/ De Souza 2012; Wirth/Bose 2007; Keim 2006).

Accordingly, using the globalisation peripheries concept can substantially improve the understanding of regional economic development in the light of demographic change. For example, McCann (2008) gives a profound economic-geographic explanation for such development trajectories, based on a bid rent model and the impacts of changing transaction costs. He illustrates how regions lose connection to global markets, thereby turning into what we call "globalisation peripheries". Less evident are ways for policymaking to reverse persistent non-growth, including demographic change. Many European examples of globalisation peripheries experience demographic change as a condition that complicates and often exacerbates their economic development prospects, but cannot easily be compensated for 
through a positive migration balance and external investment. Yet one important lesson for globalisation peripheries in the context of demographic change is that the basic assumptions for policy interventions are strikingly different, as demographic change is understood as a process that influences economic development, but is also affected by economic development itself.

\subsubsection{Case study: "Altenburger Land," a regional globalisation periphery"}

The NUTS III level region "Altenburger Land" in the East German state of Thuringia represents an example of different prototypes of demographically declining regions which also suffer from low economic development prospects (see Fig. 1). Altenburger Land has experienced quite a unique economic, social and administrative transformation in the past, but nowadays represents a marginalized and peripheralised region that is experiencing significant demographic change. Once a backbone of uranium and coal mining and its downstream industries (machinery and automotive) and farming in the former GDR, the local population grew due to policies aimed at attracting mining workers into the region. This artificial expansion of the medium-sized city region held the local economy in boom. As German reunification turned a socialist economy into a market economy, Altenburger Land faced substantial outmigration and population decline, mainly to West Germany. As competitive pressures increased and industries that were formerly shielded by state regulation lost most of their COMECON export markets, a shock-like transformation of the local economy led to the breakdown of entire industries, followed by dramatic rises in unemployment.

For this region, demographic change is associated with complex challenges in the economic, demographic, social and political spheres (Matuschewski et al. 2016; Meyer et al. 2016). Sharply decreasing fertility rates after reunification exacerbated the exodus of young, skilled persons and intensified the economic-demographic decline and stagnation dilemma of Altenburger Land. Since 1990, it has lost about 30 percent of its population and will continue to do so (1989: 130,000 inhabitants, 2014: 95,000 inhabitants, 2030 projection: 70.000 inhabitants). Moreover, the dependency ratio expected to skyrocket to 122.1 percent in 2030 (2012: 69 percent). On top of this, local young adults do not consider Altenburger Land as a place which offers any economic perspectives whatsoever. Although there have recently been signs of demographic and economic decline slowing down, the region has never recovered from the long-lasting periods of mutually reinforcing economic-demographic change and decline since the early 1990s. These negative path-dependencies influence the region's development potentials.

1 The empirical case study of "Altenburger Land“ stems from a research project "Regional Development Perspectives of Altenburger Land", which has been funded by a local public-private transfer organisation and a consortium of public organisations. The project was conducted between 2013 and 2015. See also Matuschewski et al. (2016). 
Fig. 1: "Location of Altenburger Land in East Germany" about here

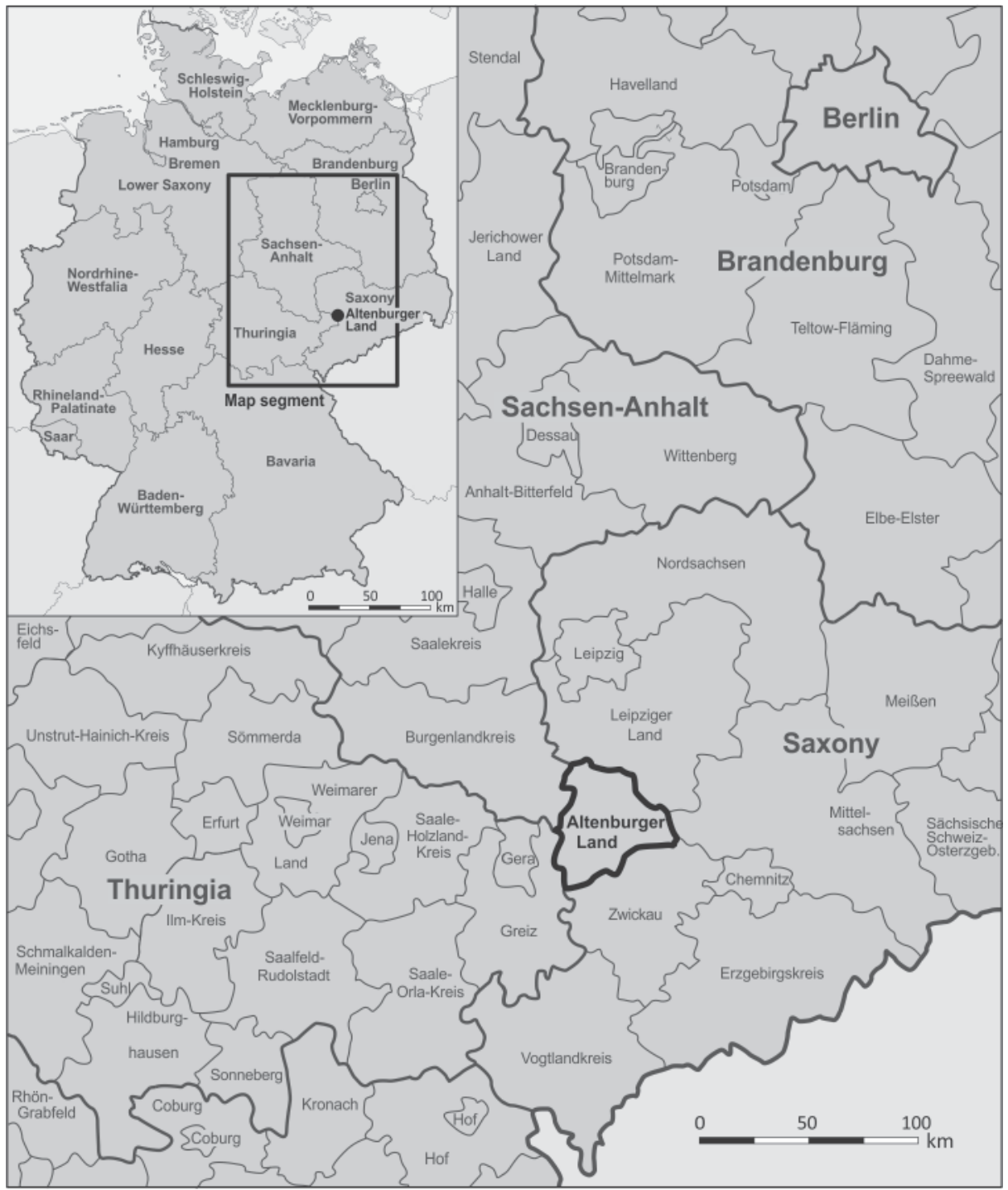

Source: Juergen Feilner, Cartography, Chair of Economic Geography of the University of Bayreuth

Inter alia, the region lacks a major or leading industry and competitive business networks that connect firms within and across industries (for example, through technologies or a common repository of knowledge). The local economy mainly consists of small and medium sized enterprises (SMEs) in low- to medium-technology industries such as mechanics, metalworking and processing, plastics, automotive, mechanical engineering, and construction. Many firms have not been able to 
integrate themselves in automotive and mechanics clusters in close geographical proximity. Ownership and management structures after the post-socialist transformation partly account for this weak economic base.

In the past years, local policy-makers experimented with various mainstream strategies to counteract the region's decline. Most of them have not proven to be success stories. Greenfield industry development combined with heavy investments in transport infrastructures (motorway and railway connections, a local airport) was one such strategy to boost economic development based on external investment and to attract firms and jobs to Altenburger Land. Because of the complex demographic-economic-social and political situation, the resulting historical pathdependencies and also the "lock-in" of local stakeholders (including policy-makers) into established growth-based approaches to combat decline clearly challenge and limit the scope for regional policy interventions in this case.

\section{Demographic change in globalisation peripheries and the resulting policy implications}

What are the general lessons for regional policymaking in the context of demographic change, based on the above criticism and using the concept of globalisation peripheries as point of departure?

First, it will be important to accept demographic-economic decline or stagnation as a complex process that is, at least partly, associated with demographic change (see Bernt et al. 2013; Haase et al. 2016a). As a matter of fact, regions facing demographic change undergo long-term systemic changes and cannot simply return to a path of economic growth. In such cases, resource limitations play an important role and preconditions for growth in the context of regional demographic change are strikingly different compared to regions with stable or growing populations, such as large agglomerations with sufficient net migration. Thus, policies for regions affected by demographic change should focus on additional and alternative goals that might not necessarily be in line with growth-oriented targets (see Bernt et al. 2013; Haase et al. 2016a). Economic stabilisation and qualitative development are appropriate adaptive approaches in such constellations to complement policies envisaging quantitative economic growth only (see Thurn 2003, and Persson 2003).

Second, and closely related to the first argument, accepting demographic change and "de-problematising" its effects in the practice of policymaking implies acknowledging that globalisation peripheries such as Altenburger Land cannot realistically hope and wait for "big investors" to initiate significant economic growth qua external investments, jobs and income. In a similar vein, external migration to such regions will be far too insignificant in most cases to compensate for population losses due to ageing and outmigration, although return migration might play some role for stabilising the regional economy, as evidence for Eastern Germany shows (Fuchs/Weyh 2016; Matuschewski/Nadler 2013). Instead, globalisation peripheries need to rely much more on local endogenous potentials in line with Hahne (1985) to shape their future development trajectory. 
Third, proactive policy approaches are clearly needed to tackle local challenges associated with demographic change (for example, population ageing and outmigration, changing labour markets or problems of family business succession) because local potentials must be identified amongst problems and deficits such as less people, less investment, less infrastructure or tax income. A proactive stance based on perceiving opportunities instead of problems is closely associated with what Steinführer et al. (2014) call "Bewaeltigungsstrategien" (coping strategies) in the context of demographic change. Coping strategies go well beyond adaptation to a declining regional economy because they include the notion of acceptance of decline and seeking ways to work with a decreasing population, reduced tax incomes and limited opportunities for public service provisions (Steinführer et al. 2014).

In summary of these lessons, asserting that decline and stagnation in both the demographic and economic realm needs to be accepted as a new, but not necessarily predetermined and unavoidable path for the future of globalisation peripheries offers scope for new ideas in policymaking beyond growth-based approaches (Rydin 2013). One important point of reference for such ideas can be the finding that the endogenous forces of demographic change matter and should therefore be integrated in the long-term approach to regional policymaking. For example, population ageing as one such endogenous challenge should not be considered as a locational disadvantage only, but as a source of local potentials: Making use of senior expertise, supporting high-quality services for the elderly, implementing local initiatives to keep skilled labour and youth in the region through the engagement of elderly residents are ideas that can be developed and capitalised on.

For globalisation peripheries, such an approach could also mean that a lack of entrepreneurs and innovation in economic areas - industrial production, service industries, etc. - should not be considered as a deficit only; instead, such a constellation can also serve as an area where policymaking could foster non-economic entrepreneurial activities and social innovation as potential local assets which aim to achieve qualitative improvements of the local social capital and networks. Social entrepreneurship is a field that does not necessarily envision quantitative sales and market growth but includes social targets. As Steinführer et al. (2014) emphasize, civic society in demographically declining areas has become part of the local infrastructure. Social entrepreneurship can thus complement the range of policy support for corporate entrepreneurship (Haugh 2006). More generally, fostering volunteerism and civic engagement of residents can be an important strategy for enhancing activities in culture, leisure and tourism, which may push economic activities "from below". In all these cases, social innovation may result from these activities, implying tighter local networks among firms and private residents and stimulating organisational learning through information and knowledge exchange among a wider circle of stakeholders (see MacCallum et al. 2009).

Policy strategies making use of social entrepreneurship and targeting social innovation in various non-economic fields may be appropriate when it comes to enlarging the scope of actors and fields of action for achieving socio-economic development despite demographic change. In particular, private and civic society initiatives can give impetus for the local economy, building regional identity through 
dense social networks and fostering "Selbstverantwortung," or local responsibility (Aring 2013; Steinführer et al. 2014). More generally, supporting endogenous potentials as sources for qualitative improvements and development, coupled with policies targeting economic growth, may enhance local opportunities more than waiting for external growth stimuli (Meng 2013; Milbert 2015; Steinführer et al. 2014), in order to address the goal of regional equivalency which is required by German constitutional law.

The stabilisation of the regional economy, even at a lower level, and economic recovery in crisis-ridden times through safeguarding the quality of life for residents can be sustainable and attainable targets for policymaking (see Wirth et al. 2016; OECD 2009b). They are far more realistic in contexts of persistent economic decline or stagnation combined with demographic change. Such qualitative improvements can have positive repercussions for public transfers, social services and local finances in the long term, even if these measures do not necessarily materialise as GDP or job growth immediately. This policy approach is closely associated with what Stöhr (1981: 39, translated from German by the authors) claimed over 30 years ago:

“Development 'from below' implies alternative criteria for factor allocation [...] and a change in the basic concept defined by economic criteria, competitive behaviour, [...] to diversified concepts defined by broader societal goals, by collaborative behaviour and endogenous motivation".

Consequently, policy-makers should strive for achieving qualitative improvements as socio-economic development in the light of demographic change and its complex challenges even if this might not directly materialise in terms of high or above-average economic growth. Such a broad approach is supported, inter alia, by the "Europe 2020" strategy on cohesion through smart, sustainable and inclusive growth (European Commission 2010).

\section{References}

Aghion, Philippe; Howitt, Peter W. 2009: The Economics of Growth. Cambridge: The MIT Press.

Aring, Jürgen 2013: Inverse Frontiers. Selbstverantwortungsräume. In: Faber, Kerstin; Oswalt, Philip (Eds.): Raumpioniere in ländlichen Regionen. Neue Wege der Daseinsvorsorge. Leipzig: spectorbooks: 42-56.

Armstrong, Martin; Taylor, Jim 2000: Regional Economics and Policy. Oxford: Blackwell.

Asheim, Bjorn T.; Gertler, Meric S. 2006: The Geography of Innovation: Regional Innovation Systems. In: Fagerberg, Jan; Mowery, David C. (Eds.): The Oxford Handbook of Innovation. Oxford: Oxford University Press: 291-317 [doi: 10.1093/oxfordhb/9780199286805.003.0011].

Azarnert, Leonid 2010: Immigration, Fertility and Human Capital. A Model of Economic Decline of the West. In: European Journal of Political Economy 26,4: 431-440 [doi: 10.1016/j.ejpoleco.2010.03.006]. 
Batey, Peter W. 2016: What Can Demographic-Economic Modelling Tell Us about the Consequences of Regional Decline? In: International Regional Science Review (published online) [doi: 10.1177/0160017616654741].

Bernt, Matthias; Liebmann, Heike 2013: Zwischenbilanz: Ergebnisse und Schlussfolgerungen des Forschungsprojektes. In: Bernt, Matthias; Liebmann, Heike (Eds.): Peripherisierung, Stigmatisierung, Abhängigkeit? Heidelberg: Springer: 218-231 [doi: 10.1007/978-3-531-19130-0_11].

Bernt, Matthias et al. 2013: How does(n't) Urban Shrinkage get onto the Agenda? Experiences from Leipzig, Liverpool, Genoa and Bytom. In: International Journal of Urban and Regional Research 38,5: 1749-1766 [doi: 10.1111/1468-2427.12101].

Blair, John P. 1995: Local economic development analysis and practice. Thousand Oaks: SAGE.

Bloom, David E.; Canning, David 2008: Global Demographic Change: Dimensions and Economic Significance. In: Prskawetz, Alexia et al. (Eds.): Population Aging, Human Capital Accumulation, and Productivity Growth. Population and Development Review 34, Supplement: New York: Population Council: 17-51.

Bloom, David E.; Sachs, Jeffrey D. 1998: Geography, Demography, and Economic Growth in Africa. In: Brookings Papers on Economic Activity 2: 207-295 [doi: 10.2307/2534695].

Bloom, David E. et al. 2003: The Demographic Dividend. A New Perspective on the Economic Consequences of Population Change. Santa Monica, CA: RAND.

Bloom, David E. et al. 2010: Implications of Population Ageing for Economic Growth. In: Oxford Review of Economic Policy 24,4: 583-612 [doi: 10.1093/oxrep/grq038].

BMI (Bundesministerium des Innern) 2016: 890.000 Tausend Asylsuchende im Jahr 2015 [URL: http://www.bmi.bund.de/SharedDocs/Pressemitteilungen/DE/2016/09/ asylsuchende-2015.html, 12.10.2016].

BMVDI (Bundesministerium für Verkehr und digitale Infrastruktur) 2016: Diskussionsforum Raumentwicklung. Der Zustrom von Flüchtlingen und die Einflüsse auf die Raumentwicklung. MORO-Informationen 14/2. Bonn [ISSN 1614-8908].

Bönte, Werner et al. 2009: The Impact of Regional Age Structure on Entrepreneurship. In: Economic Geography 85,3: 269-287 [doi: 10.1111/j.1944-8287.2009.01032.x].

Börsch-Supan, Axe/ 2008: The Impact of Global Aging on Labor, Product and Capital Markets. In: Prskawetz, Alexia et al. (Eds.): Population Aging, Human Capital Accumulation, and Productivity Growth. Population and Development Review 34, Supplement: New York: Population Council: 52-77.

Börsch-Supan, Axel 2013: Myths, scientific evidence and economic policy in an aging world. In: The Journal of the Economies of Aging 1-2: 3-15 [doi: 10.1016/j. jeoa.2013.06.001].

Boschma, Ron; Frenken, Koen 2006: Why is Economic Geography not an Evolutionary Science? Towards an Evolutionary Economic Geography. In: Journal of Economic Geography 6,3: 273-302 [doi: 10.1093/jeg/lbi022].

Boschma, Ron; Frenken, Koen 2011: The Emerging Empirics of Evolutionary Economic Geography. In: Journal of Economic Geography 11,2: 295-307 [doi: 10.1093/jeg/ lbq053].

Boschma, Ron; Martin, Ron 2007: Introduction: Constructing an Evolutionary Economic Approach. In: Journal of Economic Geography 7,5: 537-548 [doi: 10.1093/jeg/lbm021].

Bouvier, Leon F. 2001: Replacement Migration: Is it a Solution to Declining and Aging Populations? In: Population and Environment 22,4: 377-381 [doi: 10.1023/A:1006793504955]. 
Breinlich, Holger et al. 2014: Regional Growth and Regional Decline. In: Aghion, Philippe; Durlauf Steven N. (Eds.): Handbook of Economic Growth Volume 2B. North Holland: Elsevier: 683-779 [doi: 10.1016/B978-0-444-53540-5.00004-5].

Bristow, Gillian; Healy, Adrian 2014: Regional Resilience: An Agency Perspective. In: Regional Studies 48,5: 923-935 [doi: 10.1080/00343404.2013.854879].

Bristow, Gillian 2005: Everyone's a Winner: Problematising the Discourse of Regional Competitiveness. In: Journal of Economic Geography 5,3: 285-304 [doi: 10.1093/jeg/ Ibh063].

Bröcker, Johannes; Fritsch, Michael 2012: Ökonomische Geographie. München: Vahlen.

Brown, Ross; Danson, Mike 2003: 'Going grey': Demographic change and the changing labour market in Scotland. In: Local Economy 18,4: 291-305 [doi: 10.1080/0269094032000154997].

Brunow, Stephan; Hirte, Georg 2006: Age Structure and Regional Economic Growth. In: Jahrbuch für Regionalwissenschaft 26,1: 3-23 [doi: 10.1007/s10037-005-0075-4].

Camagni, Roberto 1991: Innovation Networks: Spatial Perspectives. London: Belhaven Press.

Canton, Erik J.F. et al. 2002: Vested Interests, Population Ageing, and Technology Adoption. In: European Journal of Political Economy 18,4: 631-652 [doi: 10.1016/S01762680(02)00112-X].

Capello, Roberta; Nijkamp, Peter (Eds.) 2008: Handbook of Regional Growth and Development Theories. Cheltenham: Edward Elgar.

Clark, David A. 2005: The Capability Approach: Its Development, Critiques and Recent Advances. Global Poverty Research Group Working Paper GPRG-WPS-032. Department of Economics. Oxford: University of Oxford.

Clark, Gordon L. et al. (Eds.) 2000: The Oxford Handbook of Economic Geography. Oxford: Oxford University Press.

Coe, Neil M. et al. 2013: Economic Geography: a contemporary introduction. Oxford: Blackwell.

Copus, Andrew; Skuras, Dimitris 2006: Business Networks and Innovation in Selected Lagging Areas of the European Union: A Spatial Perspective. In: European Planning Studies 14,1: 79-93 [doi: 10.1080=09654310500339885].

Cortinovis, Jean et al. 2016: Quality of government and social capital as drivers of regional diversification in Europe. Papers in Evolutionary Economic Geography 16.10. Utrecht University: Utrecht.

Crescenzi, Ricardo; Rodriguez-Pose, Andrès 2012: Infrastructure and Regional Growth in the European Union. In: Papers in Regional Science 91,3: 487-513 [doi: 10.1111/j.1435-5957.2012.00439.x].

Crescenzi, Ricardo et al. 2007: The Territorial Dynamics of Innovation. A Europe-United States Comparative Analysis. In: Journal of Economic Geography 7,6: 673-709 [doi: 10.1093/jeg/lbm030].

Cutler, David M. et al. 1990: An Aging Society: Opportunity or Challenge? In: Brookings Paper on Economic Activity 1: 1-73 [doi: 10.2307/2534525].

Dalgaard, Carl-Johan; Kreiner, Claus Thustrup 2003: Endogenous Growth: A Knife Edge or the Razor's Edge? In: Scandinavian Journal of Economics 105,1: 73-85 [doi: 10.1111/1467-9442.00005]. 
Danson, Mike; De Souza, Peter 2012: Periphery and Marginality: Definitions, Theories, Methods and Practice. In: Danson, Mike; De Souza, Peter (Eds.): Regional Development in Northern Europe. Peripherality, Marginality and Border Issues. London: Routledge: 1-15.

Davoudi, Simin et al. 2010: The Ageing of Europe: Demographic Scenarios of Europe's Futures. In: Futures 42,8: 794-803 [doi: 10.1016/j.futures.2010.04.011].

Disney, Richard 2000: Declining Public Pensions in an Era of Demographic Ageing: Will Private Provision Fill the Gap? In: European Economic Review 44,4-6: 957-973 [doi: 10.1016/S0014-2921(99)00063-X].

Dixon, Sylvia 2003: Implications of Population Ageing for the Labour Market. In: National Office of Statistics (Ed.): Labour Market Trends, Special feature. London: Office for National Statistics: 67-76.

Doran, Justin; Fingleton, Bernard 2016: Employment Resilience in Europe and the 2008 Economic Crisis: Insights from Micro-Level Data. In: Regional Studies 50,4: 644-656 [doi: 10.1080/00343404.2015.1088642].

Durth, Rainer et al. 2002: Neue Entwicklungsökonomik. Stuttgart: Lucius und Lucius/ UTB.

Ehrlich, Isaac; Lui, Francis 1997: The Problem of Population and Growth: A Review of the Literature from Malthus to Contemporary Models of Endogenous Population and Endogenous Growth. In: Journal of Economic Dynamics and Control 21,1: 205-242 [doi: 10.1016/0165-1889(95)00930-2].

Ermisch, John 1995: Demographic Development and European Labour Markets. In: Scottish Journal of Political Economy 42,3: 331-346 [doi: 10.1111/j.1467-9485.1995. tb01162.x].

European Commission 2010: Europe 2020: A European Strategy for Smart, Sustainable and Inclusive Growth. Luxembourg: Publications Office of the European Union.

Fagerberg, Jan et al. 1997: Technology, Growth and Unemployment Across European Regions. In: Regional Studies 31,5: 457-466 [doi: 10.1080/00343409750132252].

Faggian, Allessandra; McCann, Philip 2009: Human Capital and Regional Development. In: Capello, Roberta; Nijkamp, Peter (Eds.): Handbook of Regional Growth and Development Theories: Cheltenham: Edward Elgar: 133-151.

Feng, Xiao; Yang, Qian 2007: Raumstrukturelle Effekte des Bevölkerungsrückgangs. In: Feng, Xiao; Popescu, Alina M. (Eds.): Infrastrukturprobleme bei Bevölkerungsrückgang. Berlin: Berliner Wissenschaftsverlag: 49-64.

Ferry, Martin; Vironen, Heidi 2011: Dealing with Demographic Change: Regional Policy Responses. In: Geopolitics, History and International Relations 3,1: 25-58.

Feyrer, James 2008: Aggregate Evidence on the Link Between Age Structure and Productivity. In: Prskawetz, Alexia et al. (Eds.): Population Aging, Human Capital Accumulation, and Productivity Growth. Population and Development Review 34, Supplement: New York: Population Council: 78-99.

Friedman, John 1966: Regional Development Policy. A Case Study of Venezuela. Cambridge Mass. London: MIT Press.

Friedrich, Peter; Woon Nam, Chang 2009: Economic Decline and Public Intervention: Do Special Economic Zones Matter? In: Capello, Roberta; Nijkamp, Peter (Eds.): Handbook of Regional Growth and Development theories. Cheltenham: Edward Elgar: 495523. 
Fuchs, Johann et al. 2008: Demographic Effects on the German Labour Supply. A Decomposition Analysis. IAB Discussion Paper 31. Nürnberg: IAB Institute for Employment Research.

Fuchs, Johann et al. 2010: Demografischer Wandel löst langfristig Abwärtsspirale aus. Entwicklung von Beschäftigung und Erwerbspersonenpotenzial in Ostdeutschland. In: Salzmann, Thomas et al. (Eds.): Wirtschaftspolitische Herausforderungen des demografischen Wandels. Wiesbaden: VS Verlag: 15-34 [doi: 10.1007/978-3-531-924892_2].

Fuchs, Michaela; Weyh, Antje 2016: Rückwanderung von Beschäftigten nach Ostdeutschland: Räumliche Muster und soziodemographische Strukturen. In: Ifo Dresden berichtet 3: 19-27.

Fuduric, Nikolina 2012: Entrepreneurship in the Periphery. A Resource Perspective. In: Danson, Mike; De Souza, Peter (Eds.): Regional Development in Northern Europe. Peripherality, Marginality and Border Issues. London: Routledge: 164-181.

Gaigné, Carl; Thisse, Jacques-François 2009: Aging Nations and the Future of Cities. In: Journal of Regional Science 49,4: 663-688 [doi: 10.1111/j.1467-9787.2009.00629.x].

Goebel, Jan; Grabka, Markus M. 2011: Entwicklung der Altersarmut in Deutschland. In: Vierteljahrshefte zur Wirtschaftsforschung 80: 101-118 [doi: 10.3790/vjh.80.2.101].

Goldstein, Joshua F.; Kluge, Fanny 2016: Demographic Pressures on European Unity. In: Population and Development Review 42,2: 299-304 [doi: 10.1111/j.17284457.2016.00137.x].

Grabher, Gernot 1993: The Embedded Firm. On the Socioeconomics of Industrial Networks. London: Routledge.

Gunkel, Stephan; Henn, Sebastian 2016: Demographischer Wandel im ländlichen Raum. Unternehmerische Herausforderungen und Handlungsfelder am Beispiel Eichsfeld. In: Geographische Rundschau 9: 46-51.

Haase, Annegret et al. 2016a: Urban shrinkage as an emerging concern for European policymaking. In: European Urban and Regional Studies 23,1: 103-107 [doi: 10.1177/0969776413481371].

Haase, Annegret et al. 2016b: Varieties of shrinkage in European Cities. In: European Urban and Regional Studies 23,1: 86-102 [doi: 10.1177/0969776413481985].

Hahne, Ulf 1985: Regionalentwicklung durch Aktivierung intraregionaler Potentiale. Zu den Chancen „endogener" Entwicklungsstrategien. Kiel: Schriften des Instituts für Regionalforschung der Universität Kiel.

Hammer, Bernhard et al. 2015: Production Activities and Economic Dependency by Age and Gender in Europe: A Cross-Country Comparison. In: The Journal of the Economics of Ageing 5: 86-97 [doi: 10.1016/j.jeoa.2014.09.007].

Hanink, Dean M. 2010: Perspectives on Regional Change: A Review Essay on 'Handbook of Regional Growth and Development Theories'. In: Growth and Change 41,1: 3-27 [doi: 10.1111/j.1468-2257.2009.00515.x].

Hansen, Teis; Coenen, Lars 2015: The Geography of Sustainability Transitions: Review, Synthesis and Reflections on an Emergent Research Field. In: Environmental Innovation and Societal Transitions 17: 92-109 [doi: 10.1016/j.eist.2014.11.001].

Harfst, Jörn; Wirth, Peter 2014: Zur Bedeutung endogener Potenziale in klein- und mittelständisch geprägten Regionen. Überlegungen vor dem Hintergrund der Territorialen Agenda 2020. In: Raumforschung und Raumordnung 72,6: 463-475 [doi: 10.1007/ s13147-014-0312-9]. 
Harhoff, Dietmar 2008: Innovation, Entrepreneurship und Demographie. In: Perspektiven der Wirtschaftspolitik 9, issue supplement s1: 46-72 [doi: 10.1111/j.14682516.2008.00274.x].

Harrigan, Frank et al. 1992: Imperfect Competition in Regional Labour Markets: A Computable General Equilibrium Analysis. In: Environment and Planning A 24,10: 14631481 [doi: 10.1068/a241463].

Hassink, Robert 2010: Locked in Decline? On the Role of Regional Lock-in's in Old Industrial areas. In: Boschma, Ron; Martin, Ron (Eds.): Handbook of Evolutionary Economic Geography. Cheltenham: Edward Elgar: 450-468 [doi: 10.4337/9781849806497.00031].

Haug, Peter 2004: Declining population and rising costs for municipal services. In: Wirtschaft im Wandel 11: 306-312.

Haugh, Helen 2006: Social Enterprise: Beyond Economic Outcomes and Individual Returns. In: Mair, Johanna; Robinson, Jeffrey; Hockerts, Kai (Eds.): Social Entrepreneurship. New York: Palgrave MacMillan: 180-205.

Hayter, Roger et al. 1999: Business Segmentation and Location Revisited: Innovation and the Terra Incognita of Large Firms. In: Regional Studies 33,5: 425-442 [doi: 10.1080/00343409950081275].

Headey, Derek D.; Hodge, Andrew 2009: The Effect of Population Growth on Economic Growth: A Meta-Regression Analysis of the Macroeconomic Literature. In: Population and Development Review 35,2: 221-248 [doi: 10.1111/j.1728-4457.2009.00274.x].

Henning, Martin et al. 2013: Path Dependence Research in Regional Economic Development: Cacophony or Knowledge Accumulation? In: Regional Studies 47,8: 1348-1362 [doi: 10.1080/00343404.2012.750422].

Hirschmann, Alfred O. 1958: The Strategy of Economic Development. New Haven Conn./ London: Yale University Press.

Huggins, Robert; Johnston, Andrew 2009: Knowledge Networks in an Uncompetitive Region. In: Growth and Change 40,2: 227-259 [doi: 10.1111/j.1468-2257.2009.00474.x].

Keim, Karl-Dieter 2006: Peripherisierung ländlicher Räume. In: Aus Politik und Zeitgeschichte 37: 3-23.

Kim, Tae-Jeong; Hewings, Geoffrey J.D. 2013: Endogenous Growth in an Aging Economy Evidence and Policy Measures. In: Annals of Regional Science 50,3: 705-730 [doi: 10.1007/s00168-012-0527-z].

Kohlbacher, Florian; Herstatt, Cornelius 2011: The Silver Market Phenomenon: Marketing and Innovation in the Aging Society. Heidelberg: Springer.

Kühn, Manfred 2013: Peripheralization: Theoretical Concepts Explaining Socio-Spatial Inequalities. In: European Planning Studies 23,2: 367-378 [doi: 10.1080/09654313.2013.862518].

Kühn, Manfred; Bernt, Matthias 2013: Peripheralization and power. In: Fischer-Tahir, Andrea; Naumann, Matthias (Eds.): Peripheralization: the making of spatial dependencies and social injustice. Wiesbaden: Springer: 302-317 [doi: 10.1007/978-3-531-190181_15].

Küpper, Patrick 2015: Demographischer Wandel und nachlassende Wirtschaftskraft. In: Geographische Rundschau 67,9: 18-24.

Küpper, Patrick; Margarian, Anne 2010: Versteckte Dynamik - wirtschaftliche Innovationen in ländlichen Räumen. In: Europa Regional 18,2-3: 79-94. 
Lang, Thilo 2015: Socio-Economic and Political Responses to Regional Polarisation and Socio-Spatial Peripheralisation in Central and Eastern Europe: A Research Agenda. In. Hungarian Geographical Bulletin 64,3: 171-185 [doi: 10.15201/hungeobull.64.3.2].

Lang, Thilo 2012: How Do Cities and Regions Adapt to Socio-Economic Crisis? Towards an Institutionalist Approach to Urban and Regional Resilience. In: Raumforschung und Raumordnung 70,4: 285-291 [doi: 10.1007/s13147-012-0170-2].

Lang, Thilo et al. 2015: Understanding New Geographies of Central and Eastern Europe. In: Lang, Thilo et al. (Eds.): Understanding Geographies of Polarization and Peripheralization: Perspectives from Central and Eastern Europe and Beyond. Basingstoke: Palgrave Macmillan: 1-21.

Leibfritz, Willi; Roeger, Werner 2008: The Effects of Aging on Labor Markets and Economic Growth. In: Hamm, Ingrid et al. (Eds.): Demographic Change in Germany. The Economic and Fiscal Consequences. Berlin: Springer: 35-63 [doi: 10.1007/978-3-54068137-3_3].

Leyshon, Andrew et al. (Eds.) 2011: The SAGE Handbook of Economic Geography. Los Angeles: SAGE.

Liao, Pei-Ju 2011: Does Demographic Change Matter for Growth? In: European Economic Review 55, 5: 659-677 [10.1016/j.euroecorev.2010.09.006].

Liou, Kuo-Tsai (Ed.) 1998: Handbook of Economic Development. New York: Dekker.

Lisenkova, Katerina et al. 2010: Scotland the Grey: A Linked Demographic-Computable General Equilibrium (CGE). Analysis of the Impact of Population Aging and Decline. In: Regional Studies 44,10: 1351-1368 [doi: 10.1080/00343400701654228].

Lombardini, Siro 1996: Growth and Economic Development. Cheltenham: Edward Elgar.

MacCallum, Diane et al. 2009: Social Innovation and Territorial Development. Farnham: Ashgate.

MacKinnon, Danny et al. 2009: Evolution in Economic Geography: Institutions, Political Economy, and Adaptation. In: Economic Geography 85,2: 29-150 [doi: 10.1111/j.19448287.2009.01017.x].

Maier, Günther; Tödtling, Franz 2002: Regional- und Stadtökonomik 2. Regionalentwicklung und Regionalpolitik. Wien: Springer.

Martin, Ron 2015: Rebalancing the Spatial Economy: The Challenge for Regional Theory. In: Territory, Politics, Governance 3,3: 235-272 [doi: 10.1080/21622671.2015.1064825].

Martin, Ron et al. 2016: How Regions React to Recessions: Resilience and the Role of Economic Structure. In: Regional Studies 50,4: 561-585 [doi: 10.1080/00343404.2015.1136410].

Martin, Ron; Sunley, Peter 1998: Slow Convergence? The New Endogenous Growth Theory and Regional Development. In: Economic Geography 74,3: 201-227 [doi: 10.1111/j.1944-8287.1998.tb00113.x].

Martin, Ron; Sunley, Peter 2006: Path Dependence and Regional Economic Evolution. In: Journal of Economic Geography 6,4: 395-437 [doi: 10.1093/jeg/lbl012].

Mason, Andrew et al. 2016: Demographic Dividends, Human Capital, and Savings. In: The Journal of the Economics of Ageing 7: 106-122 [doi: 10.1016/j.jeoa.2016.02.004].

Matuschewski, Anke et al. 2016: Growth-Paradigms and the Vicious Circle of EconomicDemographic Decline: A View from an East German Region. In: Regions 302,1: 3-4. 
Matuschewski, Anke; Leick, Birgit 2012: Wirtschaftsentwicklung in demographischen Schrumpfungsregionen. Unternehmerische Herausforderungen und Strategien am Beispiel von Oberfranken. In: Raumforschung und Raumordnung 70,6: 515-530 [doi: 10.1007/s13147-012-0200-0].

Matuschewski, Anke; Nadler, Robert 2013: Ostdeutsche Rückwanderer und der Fachkräftemangel: Die Sicht ostdeutscher Unternehmen. In: Berichte. Geographie und Landeskunde 87,4: 419-440.

McCann, Philip 2008: Globalization and Economic Geography: The World is Curved, Not Flat. In: Cambridge Journal of Regions, Economy and Society 1,3: 351-370 [doi: 10.1093/cjres/rsn002].

McCann, Philip 2013: Modern Urban and Regional Economics. Oxford: Oxford University Press.

McMorrow, Kieran; Röger, Werner 2004: The Economic and Financial Market Consequences of Global Ageing. Berlin: Springer [doi: 10.1007/978-3-540-24821-7].

Meili, Rahel; Mayer, Heike 2015: Neue Zuwanderung und Unternehmensgründung von Migrantinnen und Migranten in peripheren Berggebieten in der Schweiz. In: Geographische Rundschau 67,9: 42-48.

Meng, Rüdiger 2013: Entrepreneurial Innovation Capability or Rural Regions: An Underestimated Phenomena? In: Tamásy, Christine; Revilla Diez, Javier (Eds.): Regional Resilience, Economy and Society. Globalising Rural Places. Farnham: Ashgate: 173-194.

Meyer, Frank; Miggelbrink, Judith; Schwarzenberg, Tom 2016: Reflecting on the Margins: Socio-spatial Stigmatisation among Adolescents in a Peripheralised Region. In: Comparative Population Studies 41,3-4 [doi: 10.12765/CPoS-2016-10en].

Milbert, Antonia 2015: Was passiert in schrumpfenden und wachsenden Kommunen und welche Konsequenzen sollen/können gezogen werden? In: Bundesinstitut für Bau-, Stadt- und Raumforschung (Ed.): BBSR-Analysen KOMPAKT 12: 13-15.

Misoulis, Nicholas 2008: Demographic Effects on Economic Growth and Consequences for the Provision of Pensions. In: Economic Affairs 28,1: 29-34 [doi: 10.1111/j.14680270.2008.00797.x].

Müller, Bernhard 2003: Regionalentwicklung unter Schrumpfungsbedingungen. Herausforderung für die Raumplanung in Deutschland. In: Raumforschung und Raumordnung 61,1-2: 28-42 [doi: 10.1007/BF03183073].

Myrdal, Gunnar 1974: Ökonomische Theorie und regionale Entwicklung. Frankfurt am Main: Fischer.

Naumann, Matthias; Bernt, Matthias 2009: When The Tap Stays Dry: Water Networks in Eastern Germany. In: Local Environment 14,5: 461-471 [doi: 10.1080/13549830902903781].

Nelson, Richard R. 1992: National Systems of Innovation. London: Pinter.

Niephaus, Yasemin et al. 2016: Handbuch Bevölkerungssoziologie. Wiesbaden: Springer VS.

Noronha Vaz, Teresa de et al. 2006: The New Rurality: Strategies for Small Firms. Aldershot: Ashgate.

Organisation for Economic Co-operation and Development 2009a: How Regions Grow. Paris: OECD.

Organisation for Economic Co-operation and Development 2009b: Regions Matter. Economic Recovery, Innovation and Sustainable Growth. Paris: OECD. 
Persson, Lars Olof 2003: Anpassungsstrategien für Regionen mit starkem Bevölkerungsrückgang - Gibt es solche Strategien in Schweden? In: Informationen zur Raumentwicklung 12: 719-723.

Pike, Andy et al. (Eds.) 2011: Handbook of Local and Regional Development. London: Routledge.

Pike, Andy et al. 2016: Shifting Horizons in Local and Regional Development. In: Regional Studies 50,5: 1-12 [doi: 10.1080/00343404.2016.1158802].

Poot, Jacques 2008: Demographic Change and Regional Competitiveness: The Impact of Immigration and Aging. In: International Journal of Foresight and Innovation Policy 4,1-2: 129-145 [doi: 10.1504/IJFIP.2008.01691].

Porter, Michael E. 1990: The Competitive Advantage of Nations. New York: Free Press.

Poterba, James M. 1998: Demographic Change, Intergenerational Linkages, and Public Education. In: American Economic Review 88,2: 315-320 [http://www.jstor.org/stable/116940, 16.05.2017].

Prettner, Klaus 2013: Population Ageing and Endogenous Economic Growth. In: Journal of Population Economics 26,2: 811-834 [doi: 10.1007/s00148-012-0441-9].

Prskawetz, Alexia; Lindh, Thomas 2007: The Relationship Between Demographic Change and Economic Growth in the EU. Vienna Institute of Demography, Austrian Academy of Sciences, Research Report No. 32.

Richardson, Harry W. 1973: Regional Growth Theory. New York: Wiley.

Richardson, Harry W. 1980: Polarization Reversal in Developing Countries. In: Papers of the Regional Science Association 45,1: 67-85 [doi: 10.1111/j.1435-5597.1980.tb01101.x].

Rosenfeld, Martin T.W. 2003: Auswirkungen des Bevölkerungsrückgangs auf die räumliche Verteilung von unternehmerischen Aktivitäten. In: Müller, Bernhard; Siedentop, Stephan (Eds.): Räumliche Konsequenzen des demographischen Wandels. Teil 1: Schrumpfung. neue Herausforderungen für die Regionalentwicklung in Sachsen/ Sachsen-Anhalt und Thüringen. Hannover: Akademie für Raumforschung und Landesplanung: 68-80.

Rosenfeld, Martin T.W. 2006: Demographischer Wandel, unternehmerische Standortentscheidungen und regionale Disparitäten am Standort. In: Gans, Paul; SchmitzVeltin, Ansgar (Eds.): Demographische Trends in Deutschland. Folgen für Städte und Regionen. Hannover: Akademie für Raumforschung und Landesplanung: 65-83.

Russell, Andrew; Vinsel, Lee 2015: Hail the maintainers. Capitalism excels at innovation but is failing at maintenance, and for most lives it is the maintenance that matters more. In: Aeon Essays: 1-14 [https://aeon.co/essays/innovation-is-overvalued-maintenance-often-matters-more, 16.05.2017].

Rydin, Yvonne 2013: The Future of Planning. Beyond Growth Dependence. Bristol: Policy Press.

Scholz, Fred 2003: Globalisierung und „neue Armut". In: Geographische Rundschau 55,10: 4-10.

Scholz, Fred 2004: Geographische Entwicklungsforschung. Stuttgart: Bornträger.

Scholz, Fred 2007: Entwicklungsländer. Braunschweig: Westermann.

Schulz, Christian 2012: Post-Wachstums-Ökonomien - (k)ein Thema für die Wirtschaftsgeographie? In: Zeitschrift für Wirtschaftsgeographie 56,1-2: 264-273 [doi: 10.1515/ zfw.2012.0018].

Sen, Amartya 2001: Development as Freedom. Oxford: Oxford University Press. 
Setterfield, Mark 2010: Post-Keynesian Macrodynamics and Path-Dependent Growth. Trinity College Department of Economics Working Paper 10-09.

Simon, Hermann 2012: Hidden Champions - Aufbruch nach Globalia. Die Erfolgsstrategien unbekannter Weltmarktführer. Frankfurt am Main: Campus.

Steinführer, Annett 2015: „Landflucht“ und „sterbende Städte“. Diskurse über räumliche Schrumpfung in Vergangenheit und Gegenwart. In: Geographische Rundschau 67,9: 4-10.

Steinführer, Annett et al. 2014: Anpassen und Bewältigen: Strategien zur Sicherung von Lebensqualität in einer schrumpfenden Alterungsregion. In: Comparative Population Studies 39,2: 319-344 [doi: 10.12765/CPoS-2014-07de].

Stephens, Heather M.; Partridge, Mark D. 2011: Do Entrepreneurs Enhance Economic Growth in Lagging Regions? In: Growth and Change 42,4: 431-465 [doi: 10.1111/j.14682257.2011.00563.x].

Sternberg, Rolf 2005: A Regional Perspective on Entrepreneurship. In: Entrepreneurial Spirit in Cities and Regions. Bollschweil: Hagbarth Publications: 38-46.

Stiglitz, Joseph E. 2001: An Agenda for the New Development Economy. Background Paper for the UNRSID Conference: The Need to Rethink Development Economics. 7.-8. September Capetown. Geneva: UNRISD.

Stimson, Robert J. et al. 2006: Regional Economic Development. Analysis and Planning Strategy. Heidelberg: Springer.

Stöhr, Walther B. 1981: Development from below: The Bottom-Up and Periphery-Inward Development Paradigm. In: Stöhr, Walther B.; Taylor, D.R. Fraser (Eds.): Development from Above or Below? The Dialectics of Regional Planning in Developing Countries. Chichester: Wiley: 39-72.

Storper, Michael 1997: The Regional World. New York: Guildford Press.

Thurn, Thomas 2003: Handlungsansätze für ländliche Regionen mit starkem Bevölkerungsrückgang. In: Informationen zur Raumentwicklung 12: 709-717.

Tyers, Rod; Shi, Qun 2012: Global Demographic Change, Labour Force Growth, and Economic Performance. In: lanchovichina, Elena l.; Walmsley, Terry L. (Eds.): Dynamic Modeling and Applications for Global Economic Analysis. Cambridge: Cambridge University Press: 342-378.

van der Gaag, Nicole; de Beer, Joop 2014: From Demographic Dividend to Demographic Burden: The Impact of Population Ageing on Economic Growth in Europe. In: Tijdschrift voor Economische en Sociale Geografie 106,1: 94-109 [doi: 10.1111/tesg.12104].

Wagner, Joachim; Sternberg, Rolf 2005: Personal and Regional Determinants of Entrepreneurial Activities: Empirical Evidence from the Regional Entrepreneurship Monitor (REM). In: Jahrbuch für Regionalwissenschaft 25,1: 91-105.

Weber, Lars 2010: Demographic Change and Economic Growth. Simulations on Growth Models. Heidelberg: Physica.

Wiechmann, Thorsten; Pallagst, Karina M. 2012: Urban shrinkage in Germany and the USA: A Comparison of Transformation Patterns and Local Strategies. In: International Journal of Urban and Regional Research 36,2: 261-280 [doi: 10.1111/j.14682427.2011.01095.x].

Winkel, Rainer; Spiekermann, Klaus 2014: Deutschland in Europa: Ergebnisse des Programms ESPON 2013. Heft 4: Demographischer Wandel und Daseinsvorsorge. Bonn: Bundesinstitut für Bau-, Stadt- und Raumforschung im Bundesamt für Bauwesen und Raumordnung. 
Wirth, Peter; Bose, Marc (Eds.) 2007: Schrumpfung an der Peripherie. Ein Modellvorhaben - und was Kommunen daraus lernen können. München: oekom.

Wirth, Peter et al. 2016: Peripheralisation of Small Towns in Germany and Japan - Dealing with Economic Decline and Population Loss. In: Journal of Rural Studies 47, Part A: 62-75 [doi: 10.1016/j.jrurstud.2016.07.021].

Prof. Dr. Anke Matuschewski $(\varangle)$, Marcel Demuth. University of Bayreuth. Bayreuth, Germany.

E-mail: anke.matuschewski@uni-bayreuth.de; marcel.demuth@googlemail.com URL: http://www.wigeo.uni-bayreuth.de

Associate Professor Dr. Birgit Leick. Østfold University College, Faculty of Business, Languages, and Social Sciences. Norway. E-mail: birgit.leick@hiof.no

URL: http://www.hiof.no/om-hogskolen/enheter/avdeling-for-okonomi_-sprak-ogsamfunnsfag/om-avdelingen/ansatte 


\section{Comparative Population Studies}

wWW.comparativepopulationstudies.de

ISSN: 1869-8980 (Print) - 1869-8999 (Internet)

\section{Published by}

Prof. Dr. Norbert F. Schneider

Federal Institute for Population Research D-65180 Wiesbaden / Germany

\section{(cc) BY-SA}

2017

\section{Managing Editor}

Frank Swiaczny

\section{Assistant Managing Editor}

Katrin Schiefer

\section{Copy Editor}

(Selected Articles in German)

Dr. Evelyn Grünheid

\section{Layout}

Beatriz Feiler-Fuchs

E-mail: cpos@bib.bund.de

\section{Scientific Advisory Board}

Paul Gans (Mannheim)

Karsten Hank (Cologne)

Johannes Huinink (Bremen)

Michaela Kreyenfeld (Rostock)

Marc Luy (Vienna)

Notburga Ott (Bochum)

Peter Preisendörfer (Mainz)

Nikola Sander (Groningen)

Zsolt Spéder (Budapest)

\section{Board of Reviewers}

Martin Abraham (Erlangen)

Laura Bernardi (Lausanne)

Hansjörg Bucher (Bonn)

Claudia Diehl (Konstanz)

Andreas Diekmann (Zurich)

Gabriele Doblhammer-Reiter (Rostock)

Jürgen Dorbritz (Wiesbaden)

Anette Eva Fasang (Berlin)

E.-Jürgen Flöthmann (Bielefeld)

Alexia Fürnkranz-Prskawetz (Vienna)

Beat Fux (Salzburg)

Joshua Goldstein (Berkeley)

Sonja Haug (Regensburg)

Hill Kulu (Liverpool)

Aart C. Liefbroer (The Hague)

Kurt Lüscher (Konstanz)

Emma Lundholm (Umeå)

Nadja Milewski (Rostock)

Dimiter Philipov (Vienna)

Roland Rau (Rostock)

Tomáš Sobotka (Vienna)

Jeroen Spijker (Barcelona)

Olivier Thévenon (Paris)

Helga de Valk (Brussels)

Heike Trappe (Rostock)

Michael Wagner (Cologne) 